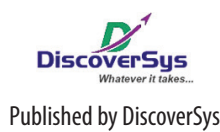

Published by DiscoverSys

\section{Association between the use of insecticide-treated bed net and malaria infection in Ende District, East Nusa Tenggara}

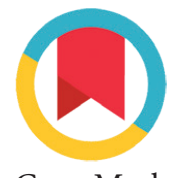

CrossMark
Maria Salestina Sekunda, ${ }^{1,2^{*}}$ Anak Agung Sagung Sawitri, ${ }^{2,3}$ Pande Putu Januraga $a^{2,4}$

\section{ABSTRACT}

Background and purpose: Malaria is a public health problem in Eastern Indonesia, especially in East Nusa Tenggara. Insecticidetreated bed net was massively distributed in 2014, however the incidence of malaria in Ende District remains high. This study aims to examine association between the use of insecticide-treated bed net and malaria infection.

Methods: A case control study was conducted in Wewaria Subdistrict, Ende District in 2016 involving 67 cases and 134 controls. Data on the use of insecticide-treated bed net which include methods of net use, net use practice, net maintenance and its current conditions were obtained through interviews and observations. Physical conditions of respondent's house that include conditions of the wall, floor, window, ventilation, ceiling and lighting were also documented through observations. Data were analysed using logistic regression.

Results: Case and control groups were comparable for gender $(p=1)$, age $(p=0.9)$, education level $(p=0.9)$ and occupation $(p=0.6)$. This study found that five variables were associated with malaria infection: irregular use of the insecticide-treated bed net $(A O R=4.08 ; 95 \% \mathrm{Cl}$ : 1.87-8.89), torn net $(A O R=2.23 ; 95 \% \mathrm{Cl}: 1.10-4.54)$, inadequate lighting ( $A O R=3.64 ; 95 \% \mathrm{Cl}$ : $1.77-7.47)$, humid floor $(A O R=3.02$; 95\%Cl: 1.24-7.34) and holes or broken ceiling (AOR=2.41; 95\%Cl: 1.02-5.72)

Conclusions: The use of insecticide-treated bed net and physical conditions of the house are risk factors for malaria infection.
${ }^{1}$ Health Polytechnic Ministry of Health Kupang,

${ }^{2}$ Public Health Postgraduate Program Udayana University, ${ }^{3}$ Department of Community and Preventive Medicine Faculty of Medicine Udayana University, ${ }^{4}$ School of Public Health Faculty of Medicine Udayana University

*Correspondence to: Maria Salestina Sekunda, Health Polytechnic Ministry of Health Kupang

maria.secunda@yahoo.co.id

Keywords: malaria, insecticide-treated bed nets, case control, Ende District, East Nusa Tenggara

Cite This Article: Sekunda, M.S., Sawitri, A.A.S., Januraga, P.P. 2017. Association between the use of insecticide-treated bed net and malaria infection in Ende District, East Nusa Tenggara. . Public Health and Preventive Medicine Archive 5(1): 49-53. D01:10.15562/phpma.v5i1.43

\section{INTRODUCTION}

Malaria is considered as a global health problem due to its high morbidity and mortality rates globally. ${ }^{1}$ One indicator used to measure the burden of malaria disease in a particular area is the annual parasite incidence (API), which accounts for total malaria cases over 1000 population per year. ${ }^{2}$ By the end of 2015, malaria cases globally were 214 million with the API of 2.92 per 1000 population, or three people acquired malaria infection for 1000 population every year. ${ }^{2}$ Malaria is also a public health issue in Indonesia. Data from the Indonesia Ministry of Health showed that API in Indonesia was $0.85 / 1000$ population in 2015, while in East Nusa Tenggara - one out of five provinces with high API in Indonesia, was 7.04/1000 population. ${ }^{3}$ In 2014, the total number of malaria in Ende District was 5456 cases with API of 19.54/1000 population. ${ }^{4}$

Malaria cases were distributed across Ende District which includes sub-districts of Wewaria, East Ende, Wolowaru and Nanganpanda. ${ }^{4,5}$ The majority of malaria cases found in Wewaria Sub-district were malaria falciparum with a total of 496 cases. $^{4,5}$ Ende District Health Office has delivered several programs to reduce malaria transmission including the insecticide-treated bed net program. By 2014, a total of 156,191 nets were distributed to 70,071 households or at least every household received two insecticide-treated bed nets. However, until now the incidence of malaria in Ende District remains high. ${ }^{4}$

The correct use of insecticide-treated bed net is a protective factor against malaria infection because it offers physical barrier from mosquito bites. ${ }^{67,8}$ There are two types of net available for communities at this study area. First, a non-insecticide treated bed net which can be easily found in the local market. Second, an insecticide-treated bed net which is freely provided by the local government in the forms of long-term insecticide-treated bed net and re-treated dyed net. The insecticide-treated bed nets must be maintained to improve its effectiveness. The long-term treated nets offer a longer effectiveness than the re-treated dyed nets. The effectiveness of long-term treated nets will be reduced after being washed for 20 times and this effectiveness lasts for three years. On the other hand, re-treated dyed nets are effective for 6-12 months when it is washed every six months. ${ }^{6,7,8}$

Several studies in endemic areas in Indonesia have been conducted to examine association 
between the use of insecticide-treated bed net and malaria infection, however these findings are still inconsistent. ${ }^{9}$ A study in West Nusa Tenggara found that there is no association between the use of insecticide-treated bed net and malaria infection, while a study in Jayapura showed that people who mostly sleeping without mosquito net are 2.28 times more likely to get malaria than who regularly using it. ${ }^{10}$ Furthermore, a study in Sikka District - East Nusa Tenggara showed that people who do not use insecticide-treated bed net are six times more likely to get malaria than those who regularly use it. ${ }^{11}$

Even though several studies have been done to examine association between the use of insecticide-treated bed net and malaria infection, this has never been conducted in Wewaria Sub-district. Wewaria Sub-district is an endemic malaria area and insecticide-treated bed nets have also been distributed across the area. However, the malaria incidence in this area remains high. This study aims to examine the association between the use of insecticide-treated bed net and malaria infection in Wewaria Sub-district, East Nusa Tenggara.

\section{METHODS}

A case control study was conducted in Wewaria Sub-district which is the major contributor for malaria falciparum in Ende District. A total of 67 cases and 134 controls were recruited in the study. This sample size was calculated in 95\% significant level, with power of $80 \%$, proportion of controls who did not use mosquito net of $44 \%$ and odd ratio of $2 .^{12}$ Cases were selected from the 2015 register of malaria falciparum cases in Welamosa Public Health Centre. ${ }^{5}$ Controls were selected from healthy individuals who live near the cases and recorded as negative on malaria blood survey during the study period. Cases and controls were matched for sex and age (between 15-55 years with a maximum age gap between case and control is one year). Data were collected by interviews and observations.

Data on the use of insecticide-treated bed net include: net use, methods of net use, maintenance of nets and physical conditions of nets. Data on the first three items were obtained through interview while the last one was through observation. Data on physical conditions of the respondent's house were also collected which include: wall, window, floor, ceiling, ventilation and lighting. Lighting was determined by the amount of sun light went through the window and also by the window conditions which showed that it has been open or closed. Floor conditions were measured by looking at its humidity status. Physical conditions of wall, window, ceiling and ventilation were assessed by the presence of holes which allow mosquitoes to get into the house.
The methods of net use were divided into two categories: freeing the net and tugging it into the bed. Net maintenance consisted of two items: frequency of washing the net and place to hang the net. Good usage was defined if respondents regularly used the net and correctly maintained the net.

Data were analysed by calculating the adjusted odds ratio (AOR) with the backward logistic regression in order to determine association between the use of insecticide-treated bed net and malaria infection.

This study protocol has been approved by the Human Research Ethics Committee of Faculty of Medicine Udayana University/ Sanglah General Hospital.

\section{RESULTS}

Table 1 shows that cases and controls are comparable for age, sex, education and employment. Table 2 shows the bivariate analysis and reveals that several variables are associated with malaria: irregular use of insecticide-treated bed net $(\mathrm{OR}=3.62 ; 95 \% \mathrm{CI}$ : 1.83-7.16), incorrect use of insecticide-treated nets $(\mathrm{OR}=4.77$; 95\%CI: $1.06-21.08)$, torn nets $(\mathrm{OR}=2.31$; 95\%CI: 1.26-4.25), inadequate lighting $(\mathrm{OR}=3.03$; 95\%CI: 1.64-5.62), humid floor $(\mathrm{OR}=3.48$; $95 \% \mathrm{CI}$ : 1.59-7.65), broken ceiling ( $\mathrm{OR}=2.32$; 95\%CI: 1.11$4.88)$, broken windows (OR $=2.64$; 95\%CI: 1.29 5.41), holes at the wall (OR=2.03; 95\%CI: 1.04-4.12) and open ventilation or holes at the ventilation $(\mathrm{OR}=2.18$; 95\%CI: 1.10-4.33).

Table 3 shows the multivariate analysis with backward logistic regression. All variables with $p$-value of $<0.25$ were included in the analysis. Only five factors were found to have significant association with malaria infection. These variables are irregular use of net (AOR $=4.07 ; 95 \% \mathrm{CI}$ : $1.87-8.88)$, torn net $(\mathrm{AOR}=2.22 ; 95 \% \mathrm{CI}: 1.09-4.53)$, inadequate lighting ( $\mathrm{AOR}=3.63$; 95\%CI: 1.77-7.46), humid floor $(\mathrm{AOR}=3.01$; 95\%CI: 1.23-7.33) and broken ceiling $(\mathrm{AOR}=2.41 ; 95 \% \mathrm{CI}$ : 1.01-5.71).

\section{DISCUSSION}

This study shows that irregular use of insecticide-treated bed net and broken or torn net are both associated with increased risk of acquiring malaria infection. Similarly, inadequate lighting, humid floor and holes ceiling are all significant risk factors for malaria infection.

This study found that cases tend to irregularly use the net than controls ( $38.8 \%$ vs $14.9 \%)$. Irregular use of the net increases the risk to acquire malaria infection $(\mathrm{AOR}=4.01 ; 95 \% \mathrm{CI}$ : 1.87-8.89). This finding is consistent with a study in Jayapura where irregular use of mosquito-net increases the 
Table 1 Sociodemographic characteristics between cases and controls

\begin{tabular}{|c|c|c|c|c|c|}
\hline \multirow[b]{2}{*}{ Variables } & \multicolumn{2}{|c|}{ Cases } & \multicolumn{2}{|c|}{ Controls } & \multirow[b]{2}{*}{ p value } \\
\hline & $n=67$ & $\%$ & $n=134$ & $\%$ & \\
\hline Age: mean (SD), median & \multicolumn{2}{|c|}{$38(10.4), 37$} & \multicolumn{2}{|c|}{$38(10.6), 37$} & 0.9 \\
\hline Sex & & & & & 1 \\
\hline Female & 48 & 71.6 & 96 & 71.6 & \\
\hline Male & 19 & 28.4 & 38 & 28.4 & \\
\hline Education & & & & & 0.9 \\
\hline No school/not finished elementary & 5 & 7.5 & 16 & 11.9 & \\
\hline Elementary & 27 & 40.3 & 49 & 36.6 & \\
\hline Junior high & 12 & 17.9 & 20 & 14.9 & \\
\hline Senior high & 14 & 20.9 & 29 & 21.6 & \\
\hline University & 9 & 14.4 & 20 & 14.9 & \\
\hline Employment & & & & & 0.6 \\
\hline Farmer & 42 & 62.7 & 93 & 69.4 & \\
\hline Informal sector & 2 & 3.0 & 1 & 0.7 & \\
\hline Government worker & 5 & 7.5 & 9 & 6.7 & \\
\hline Housewives & 7 & 10.4 & 9 & 6.7 & \\
\hline Others & 11 & 16.4 & 22 & 16.4 & \\
\hline
\end{tabular}

Table 2 Crude odd ratio of the use of insecticide-treated bed net and physical house conditions

\begin{tabular}{|c|c|c|c|c|c|c|c|}
\hline \multirow[b]{2}{*}{ Insecticide-treated bed net } & \multicolumn{2}{|c|}{ Cases } & \multicolumn{2}{|c|}{ Controls } & \multirow[b]{2}{*}{ Crude OR } & \multirow[b]{2}{*}{$95 \% \mathrm{Cl}$} & \multirow[b]{2}{*}{ p value } \\
\hline & $\mathbf{n}$ & $\%$ & $\mathbf{n}$ & $\%$ & & & \\
\hline \multicolumn{8}{|l|}{ Net use practice } \\
\hline Irregular & 26 & 38.8 & 20 & 14.9 & 3.62 & $1.83-7.16$ & 0.00 \\
\hline Regular & 41 & 61.2 & 114 & 85.1 & & & \\
\hline \multicolumn{8}{|l|}{ Net condition } \\
\hline Torn & 32 & 47.8 & 38 & 28.4 & 2.31 & $1.26-4.25$ & 0.00 \\
\hline Good condition & 35 & 52.2 & 96 & 71.6 & & & \\
\hline \multicolumn{8}{|l|}{ Net maintenance } \\
\hline Incorrect & 64 & 95.52 & 126 & 94.03 & 1.35 & $0.35-5.28$ & 0.66 \\
\hline Correct & 3 & 4.48 & 8 & 5.97 & & & \\
\hline \multicolumn{8}{|l|}{ Method of net use } \\
\hline Incorrect & 65 & 97.01 & 117 & 87.31 & 4.77 & $1.06-21.08$ & 0.04 \\
\hline Correct & 2 & 2.99 & 17 & 12.69 & & & \\
\hline \multicolumn{8}{|l|}{ House lighting } \\
\hline Inadequate & 34 & 50.7 & 34 & 25.4 & 3.03 & $1.64-5.62$ & 0.00 \\
\hline Adequate & 33 & 49.3 & 100 & 74.6 & & & \\
\hline \multicolumn{8}{|l|}{ Floor condition } \\
\hline Humid & 58 & 86.6 & 87 & 64.9 & 3.48 & $1.59-7.65$ & 0.00 \\
\hline Not humid & 9 & 13.4 & 47 & 35.1 & & & \\
\hline \multicolumn{8}{|l|}{ House ceiling } \\
\hline Holes & 56 & 83.6 & 92 & 68.7 & 2.32 & $1.11-4.88$ & 0.03 \\
\hline Good condition & 11 & 16.4 & 42 & 31.3 & & & \\
\hline
\end{tabular}


Table 2 Continue

\begin{tabular}{|c|c|c|c|c|c|c|c|}
\hline \multirow[b]{2}{*}{ Insecticide-treated bed net } & \multicolumn{2}{|c|}{ Cases } & \multicolumn{2}{|c|}{ Controls } & \multirow[b]{2}{*}{ Crude OR } & \multirow[b]{2}{*}{$95 \% \mathrm{Cl}$} & \multirow[b]{2}{*}{ p value } \\
\hline & $\mathbf{n}$ & $\%$ & $\mathbf{n}$ & $\%$ & & & \\
\hline \multicolumn{8}{|l|}{ Window condition } \\
\hline Holes & 55 & 82.1 & 85 & 63.4 & 2.64 & $1.29-5.41$ & 0.01 \\
\hline Good condition & 12 & 17.9 & 49 & 36.6 & & & \\
\hline \multicolumn{8}{|l|}{ Wall condition } \\
\hline Holes & 54 & 80.6 & 90 & 67.2 & 2.03 & $1.04-4.12$ & 0.05 \\
\hline Good condition & 13 & 19.4 & 44 & 32.8 & & & \\
\hline \multicolumn{8}{|l|}{ Ventilation } \\
\hline Holes & 53 & 79.1 & 85 & 63.4 & 2.18 & $1.10-4.33$ & 0.03 \\
\hline Good condition & 14 & 20.9 & 49 & 36.6 & & & \\
\hline
\end{tabular}

Table3 Adjusted odd ratio of the use of insecticide-treated bed net and physical house conditions

\begin{tabular}{lccc}
\hline Variables & AOR & $\mathbf{9 5 \%} \mathbf{C l}$ & p value \\
\hline Irregular use of insecticide-treated bed net & 4.08 & $1.87-8.89$ & 0.01 \\
Torn net & 2.23 & $1.10-4.54$ & 0.03 \\
Inadequate lighting & 3.64 & $1.77-7.47$ & 0.01 \\
Humid house floor & 3.02 & $1.24-7.34$ & 0.02 \\
Broken (holes) house ceiling & 2.41 & $1.02-5.72$ & 0.05 \\
\hline
\end{tabular}

risk for malaria infection with odd ratio of $2.28 .{ }^{10}$ Furthermore, a study in West Kalimantan also found that irregular use of mosquito-net increases the risk for malaria infection with odd ratio of 3.2. ${ }^{13}$ In African settings, regular use of insecticide-treated bed net have reported to decrease morbidity associated to malaria by $50 \%{ }^{2}$ The study in Africa does not specifically mention whether the distribution of the net includes all beds of a house or not. This study however reveals that the distribution of the nets does not cover the entire beds of a house. On average, one house only receives two or three nets. For those who received the nets, they didn't use the net regularly. Some respondents stated that the net creates stuffy environment thus making them difficult to sleep. This study points out that the net using practice in Ende District is inadequate and it contributes to a high API. This might also indicate that the insecticide-treated bed net program implementation in Ende District is suboptimal. Therefore it requires more promotion and ongoing monitoring to improve regular use of mosquito-nets.

This study also found that more cases are having torn or broken nets than controls ( $47.8 \%$ vs $28.4 \%$ ). Broken or torn nets increase the risk to acquire malaria infection (AOR=2.23; 95\%CI: 1.10-4.54). This finding is consistent with study conducted in Oaxaca, Mexico which found that broken nets increase the risk for malaria infection by 5.29 times. ${ }^{14}$ Broken nets are casued by inadequate or wrong maintenance for example frequent washing (more than four times per year) and drying up directly to the sun. In fact, insecticide-treated bed net are still effective up to three years if maintained correctly. ${ }^{4,5,6,7}$ This study however is not intended to explore association between net maintenance and its efficacy. A study in South Sulawesi reveals that frequent washing and drying up directly to the sun might reduce its efficacy. ${ }^{15}$ This present study found that both cases and controls are having inadequate maintenance of the nets which may reduce its efficacy. This study also reveals that insecticide-treated bed net were not taken directly by the household member from the health workers. It resulted the household member did not receive enough information on the use and maintenance of insecticide-treated bed net. This condition also indicates that education and regular monitoring by health workers on nets maintenance are required.

This study found that physical conditions of respondents' house are also associated to malaria infection. Generally, the house condition of population in the study areas is poor that includes inadequate house lighting, humid or damp house, and holes ceiling or no ceiling. Even when the net-using behavior is good, if the house conditions are poor the likelihood of acquiring malaria infection is still 
high. This situation indicates that inter-sectoral participation in malaria control for example improving housing conditions is required.

The limitation of this study is associated with information bias provided by respondents because observation to some information cannot be made. In addition, identified risk factors in this study are assumed to happen prior to malaria infection.

\section{CONCLUSION}

Irregular use of insecticide-treated bed net, broken nets and poor physical conditions of the house are associated with malaria infection in Wewaria Subdistrict, Ende District.

\section{ACKNOWLEDGEMENT}

We would like to thank Director of Kupang Health Polytechnic, the head of School of Nursing, Kupang Health Polytechnic, the head of Welamosa Public Health Centre and all my colleagues and respondents who supported this study.

\section{REFERENCES}

1. The Millennium Development Goals Report 2015, Available at: http://www.un.org/millennium goals/2015 MDG_Report/pdf/MDG\%202015\%20rev\%20(July\%201). pdf.

2. World Health Organization (WHO). World Malaria Report; 2015. Available at http://apps. who.int/iris/ bitstream/10665/200018/1/9789 241565158_eng.pdf. 2015.

3. Ministry of Health of Indonesia. Riset Kesehatan Dasar [Basic Health Survey]. Research and Development Agency of Ministry of Health of Indonesia, Jakarta, Available at: www. Depkes.go.id/resources/download; 2013.

4. Ministry of Health of Indonesia. Pedoman Penatalaksanaan Kasus Malaria di Indonesia [Guideline on Malaria Management], Directorate General of Communicable Diseases and PLP, Jakarta; 2006.

5. Welamosa Public Health Centre. Data P2M Bidang Malaria [CDC Program Report on Malaria]; 2015.

6. Ministry of Health of Indonesia. Pedoman Ekologi dan Aspek Perilaku Vektor [Guideline on Ecology and Vector Behaviour], Directorate General of Communicable Diseases Control and Environmental Health; 2001.

7. Ministry of Health of Indonesia. Modul Epidemiologi Malaria [Epidemiology of Malaria Module], Directorate General of Communicable Diseases Control and Environmental Health, Jakarta, 2007.
8. Ministry of Health of Indonesia. Pedoman Pengendalian Vektor Malaria [Guideline on Vector Control], Directorate General of Communicable Diseases Control and Environmental Health, Jakarta; 2014.

9. Rubianti. Faktor-faktor Risiko Malaria di Wilayah Kerja Puskesmas Paruga Kota Bima Nusa Tenggara Barat [Risk factors of malaria infection in Paruga Community Health Centre, Bima City-West Nusa Tenggara]. Jurnal Kesehatan Masyarakat; 3(3):174-185. Available at: http://www. Pubmedcentral.nih.gov/ article render.fcgi?artid=3481670 \&tool=pmcentrez\&rendertype=abstract, 2009.

10. Babba. Faktor-faktor Risiko yang Mempengaruhi Kejadian Malaria (Studi Kasus di Wilayah Kerja Puskesmas Hamadi Kota Jayapura) [Risk factors associated to malaria (A case study in Hamadi Community Health Centre, Jayapura City]; 2007. Available at: core.ac.uk/download/ pdf/1717456 =abstract, 2007.

11. Adryanto AFT. Hubungan Kepatuhan Menggunakan Kelambu Berinsektisida dengan Kejadian Penyakit Malaria di Kabupaten Sikka Propinsi Nusa Tenggara Timur Tahun 2009 [Association between the regular use of insecticide-treated bed net and malaria infection in Sikka District, East Nusa Tenggara 2009] [thesis]. School of Public Health Indonesia University; 2010. Available at: http.//lib.ui.ac.id.

12. Lameshow S. Besar Sampel dalam Penelitian Kesehatan [Sample Size in Health Research]. Yogyakarta: Gadjah Mada University Press; 1990.

13. Santy. Hubungan Antara Faktor Individu dan Faktor Lingkungan dengan Kejadian Malaria di Desa Sungai Ayak 3 Kecamatan Belitang Hilir Kabupaten Sekadau [Association between individual factors and environment with malaria infection in Sungai Ayak 3 Village, Belitang Hilir Subdistrict, Sekadau Regency] [Thesis]. School of Medicine, Faculty of Medicine Tanjungpura University; 2014. Available at: http:// journal.ui.ac.id/index.php/eJKI/ article/view/3186/2478, 2014.

14. Danis-Lozano R, Rodríguez $\mathrm{MH}$, Betanzos-Reyes AF, Hernández-Avila JE, González-Cerón L, Méndez-Galván JF, et al. Individual risk factors for Plasmodium vivax infection in the residual malaria transmission focus of Oaxaca, Mexico. Salud Publica Mex; 2007; 49(3): 199-209.

15. Firmansyah, Wahid I, Arsin A. Efikasi Kelambu Berinsektisida setelah Pencucian Berulang terhadap Nyamuk Aedes Aegypti [Efficacy of insecticide-treated bed net on Aedes Aegypti mosquitoes]; 2014. http://pasca. unhas.ac.id /jurnal/files/83fcf23146d48d6b577f0aa5666ae eab.pdf 2014

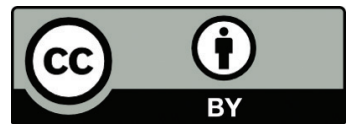

This work is licensed under a Creative Commons Attribution 